\title{
Differential Induction of Systemic Resistance in Arabidopsis by Biocontrol Bacteria
}

\author{
Saskia C. M. Van Wees, ${ }^{1,2}$ Corné M. J. Pieterse, ${ }^{1,2}$ Annemiek Trijssenaar, ${ }^{1}$ \\ Yvonne A. M. Van 't Westende, ${ }^{1}$ Femke Hartog, ${ }^{1}$ and Leendert C. Van Loon ${ }^{1,2}$ \\ ${ }^{1}$ Department of Plant Ecology and Evolutionary Biology, Section of Plant Pathology, Utrecht University, \\ P.O. Box 800.84, 3508 TB Utrecht, the Netherlands; and ${ }^{2}$ Graduate School of Experimental Plant \\ Sciences, the Netherlands \\ Received 21 November 1996. Accepted 7 May 1997.
}

Selected nonpathogenic, root-colonizing bacteria are able to elicit induced systemic resistance (ISR) in plants. To elucidate the molecular mechanisms underlying this type of systemic resistance, an Arabidopsis-based model system was developed in which Pseudomonas syringae pv. tomato and Fusarium oxysporum f. sp. raphani were used as challenging pathogens. In Arabidopsis thaliana ecotypes Columbia and Landsberg erecta, colonization of the rhizosphere by $P$. fluorescens strain WCS417r induced systemic resistance against both pathogens. In contrast, ecotype RLD did not respond to WCS417r treatment, whereas all three ecotypes expressed systemic acquired resistance upon treatment with salicylic acid (SA). P. fluorescens strain WCS374r, previously shown to induce ISR in radish, did not elicit ISR in Arabidopsis. The opposite was found for $P$. putida strain WCS358r, which induced ISR in Arabidopsis but not in radish. These results demonstrate that rhizosphere pseudomonads are differentially active in eliciting ISR in related plant species. The outer membrane lipopolysaccharide (LPS) of WCS417r is the main ISRinducing determinant in radish and carnation, and LPScontaining cell walls also elicit ISR in Arabidopsis. However, mutant WCS417rOA ${ }^{-}$, lacking the O-antigenic side chain of the LPS, induced levels of protection similar to those induced by wild-type WCS417r. This indicates that ISR-inducing bacteria produce more than a single factor that trigger ISR in Arabidopsis. Furthermore, WCS417r and WCS358r induced protection in both wildtype Arabidopsis and SA-nonaccumulating NahG plants without activating pathogenesis-related gene expression. This suggests that elicitation of an SA-independent signaling pathway is a characteristic feature of ISRinducing biocontrol bacteria.

Induced resistance is defined as an enhancement of the plant's defensive capacity against a broad spectrum of pathogens that is acquired after appropriate stimulation (reviewed by Hammerschmidt and Kuć 1995). The classic way of eliciting induced resistance is by a predisposal infection with a pathogen that causes a hypersensitive reaction. The resulting

Corresponding author: S. C. M. Van Wees; Telephone: +31 30 2537438; Fax: +31 30 2518366; E-mail: s.vanwees@boev.biol.ruu.nl elevated resistance response upon challenge inoculation of plant parts distant from the site of primary infection is known as systemic acquired resistance (SAR). SAR was first characterized in tobacco plants that expressed increased resistance systemically after infection by tobacco mosaic virus (Ross 1961). Pathogen-induced SAR is associated with an early increase in endogenously synthesized salicylic acid (SA) (Malamy et al. 1990; Métraux et al. 1990). Accumulation of SA is critical in the signaling pathway that controls SAR, since plants that do not accumulate SA are incapable of expressing induced resistance (Delaney et al. 1994; Gaffney et al. 1993). Furthermore, SAR is characterized by the activation of so-called SAR genes (Ward et al. 1991), including genes that encode pathogenesis-related (PR) proteins (Linthorst 1991; Van Loon 1985), which are often used as markers for the state of induced resistance. Both PR genes and induced resistance are expressed in plants treated with SA (Ward et al. 1991; White 1979). In addition, chemical agents such as 2,6dichloroisonicotinic acid (Métraux et al. 1991) and benzothiadiazole (Lawton et al. 1996) have been shown to induce resistance to the same spectrum of pathogens and to concurrently activate expression of SAR genes.

In 1991, an alternative approach to inducing systemic resistance was reported by Alström (1991), Van Peer et al. (1991), and Wei et al. (1991). These authors independently demonstrated that selected strains of nonpathogenic plant growth-promoting rhizobacteria, which colonize the rhizosphere of the plant, are able to elevate plant resistance. Until then, these bacteria, mainly fluorescent Pseudomonas spp., had been studied for their ability to control soilborne pathogens through competition for nutrients, siderophoremediated competition for iron, or antibiosis (Bakker et al. 1991; Schippers 1992; Thomashaw and Weller 1995). Induction of systemic resistance in the plant thus appeared to be an additional mechanism by which these bacteria could protect the plant against disease. To date, induced systemic resistance (ISR) (Kloepper et al. 1992) mediated by nonpathogenic rhizobacteria has been demonstrated in several plant species (Pieterse et al. 1996b) and shown to be effective against bacterial, viral, and fungal diseases. So far, little is known about the molecular basis underlying this type of ISR. Maurhofer et al. (1994) showed that ISR induced by $P$. fluorescens strain CHA0 in tobacco is associated with PR protein accumulation, suggesting that nonpathogen-induced 
ISR and pathogen-induced SAR share similar mechanisms. However, PR proteins did not accumulate in radish plants expressing ISR elicited by $P$. fluorescens strain WCS417r (Hoffland et al. 1995, 1996). Moreover, Pieterse et al. (1996a) demonstrated that in Arabidopsis, ISR induced by WCS417r was not associated with PR gene activation and was elicited in transgenic Arabidopsis plants unable to accumulate SA. This indicates that in contrast to pathogen-induced SAR, WCS417r-mediated ISR is controlled by an SA-independent signaling pathway.

Previously, Van Peer and Schippers (1992) and Leeman et al. (1995b) showed that the O-antigenic side chain of the outer membrane lipopolysaccharide (LPS) of strain WCS417r is the main determinant for the induction of ISR against Fusarium wilt disease in both carnation and radish. A bacterial mutant lacking the O-antigenic side chain did not induce resistance, whereas LPS-containing cell walls and purified LPS of WCS417r induced ISR to the same extent as living bacteria. Other bacterial determinants suggested to contribute to ISR are siderophores and SA (Leeman et al. 1996; Maurhofer et al. 1994).

The main objective of this study was to elucidate the basic mechanisms underlying nonpathogenic Pseudomonas spp.mediated ISR in the Arabidopsis model system. Here, we demonstrate that ISR-inducing fluorescent Pseudomonas spp. are differentially active in eliciting ISR in Arabidopsis. Furthermore, we provide evidence that in contrast to what is observed in carnation and radish, the LPS of WCS417r plays only a minor role in the elicitation of ISR in Arabidopsis, indicating that WCS417r possesses more than a single ISRinducing determinant.

\section{RESULTS}

\section{Differential expression of $P$. fluorescens WCS417r- mediated ISR in Arabidopsis.}

Recently, Pieterse et al. (1996a) demonstrated that colonization of the rhizosphere by strain WCS417r of P. fluorescens induces ISR in Arabidopsis against diseases caused by the bacterial leaf pathogen $P$. syringae pv. tomato (Whalen et al. 1991) and the fungal root pathogen Fusarium oxysporum f. sp. raphani (Leeman et al. 1995a). To investigate whether different ecotypes of $A$. thaliana are equally able to express WCS417r-mediated ISR, ecotypes Columbia (Col), Landsberg erecta (Ler), and RLD were tested in bioassays in which $P$. syringae pv. tomato and $F$. oxysporum f. sp. raphani were used as challenging pathogens. In these bioassays, the resistance-inducing potential of WCS417r was compared with that of SA, an established inducer of SAR (Malamy and Klessig 1992). Leaves of noninduced control plants challenged with $P$. syringae pv. tomato developed necrotic lesions surrounded by extensive, spreading chlorosis. Upon challenge inoculation with $F$. oxysporum f. sp. raphani, control plants showed wilting and yellowing of the leaves after 3 to 4 weeks. Induced protection against either pathogen was quantified by determining the percentage of leaves with symptoms. In plants challenge inoculated with $P$. syringae pv. tomato, proliferation of the pathogen in the leaves was assessed also. Figure $1 \mathrm{~A}$ and $\mathrm{C}$ shows that root treatment of ecotype Col with WCS417r resulted in a reduction of about $50 \%$ in the symptoms caused by either of the pathogens. The level of protection induced by WCS417r was similar to or only slightly less than that induced by SA applied to the roots as a soil drench. As shown in Figure 1B, growth of $P$. syringae pv. tomato was significantly inhibited in WCS417r- and SAtreated Col plants, indicating that the reduction in symptoms is associated with inhibition of bacterial multiplication. Ecotype Ler responded similarly to WCS417r and SA treatments. Both inducers decreased disease symptoms to the same extent (Fig. 1D and F) and caused a 20-fold reduction in bacterial multiplication in leaves challenged with $P$. syringae pv. tomato (Fig. 1E). In ecotype RLD, however, WCS417r did not reduce symptoms provoked by either pathogen (Fig. 1G and I), nor did it inhibit growth of $P$. syringae pv. tomato in challenged leaves (Fig. 1H). In contrast, treatment with SA resulted in a significant reduction in symptoms caused by either pathogen, as in ecotypes $\mathrm{Col}$ and Ler. Moreover, proliferation of $P$. syringae pv. tomato in challenged leaves was clearly decreased. These results demonstrate that WCS417r induces ISR in ecotypes Col and Ler but fails to do so in ecotype RLD, whereas in all three ecotypes SAR can be induced by SA.

To determine whether the inability of RLD to exhibit WCS417r-mediated ISR might be attributed to a less effective colonization of the roots, the population density of WCS417r in the rhizosphere of treated Col, Ler, and RLD plants was examined. Table 1 shows that the numbers of rifampicin-resistant bacteria present in the rhizosphere of the three ecotypes were of the same order of magnitude $\left(2.2-8.3 \times 10^{5} \mathrm{CFU} / \mathrm{g}\right.$ of root, fresh weight). No rifampicin-resistant bacteria were detected on nontreated roots. Therefore, it can be concluded that WCS417r colonized the rhizosphere of the three ecotypes to comparable levels.

\section{Differential ability of strains of fluorescent Pseudomonas spp. to elicit ISR.}

Previously, Leeman et al. (1995a) showed that in radish plants, strains WCS417r and WCS374r of P. fluorescens induce ISR against Fusarium wilt, whereas strain WCS358r of P. putida does not. To investigate whether Arabidopsis responds similarly, the ability of these strains to induce ISR against $P$. syringae pv. tomato or $F$. oxysporum $\mathrm{f}$. sp. raphani infection was tested. In contrast to WCS417r, WCS374r did not reduce disease symptoms provoked by either $P$. syringae pv. tomato or F. oxysporum f. sp. raphani (Fig. 2A and C), nor did it inhibit proliferation of $P$. syringae pv. tomato in challenged leaves (Fig. 2B). WCS358r induced significant ISR against both pathogens. However, the extent of symptom reduction was less than that induced by WCS417r. On the other hand, multiplication of $P$. syringae pv. tomato upon challenge was reduced almost to the same level. Whereas WCS417r induced resistance in both radish and Arabidopsis, the resistance-inducing capacities of WCS374r and WCS358r clearly differed in these two species.

To exclude the possibility that the observed protection was caused by a direct effect of the inducing Pseudomonas strains on the pathogen, their spatial separation on the plant was verified. To this end, the population densities of the rhizobacterial strains on treated and nontreated plant parts were determined at the end of each bioassay by plating root washes or leaf extracts on selective King's medium B agar plates (King et al. 1954). Table 2 shows that from WCS417r- and WCS358r-treated roots 
similar amounts of rifampicin-resistant Pseudomonas bacteria were recovered, whereas approximately 10 -fold lower numbers were detected on WCS374r-treated roots. In the leaves used for challenge inoculation with $P$. syringae pv. tomato or on the root parts inoculated with $F$. oxysporum f. sp. raphani, rifampicinresistant bacteria were never detected, demonstrating that for the duration of the bioassays, the inducing Pseudomonas strains remained spatially separated from the challenging pathogens. Moreover, in vitro antagonism assays showed no significant inhibition of growth of $P$. syringae pv. tomato or F. oxysporum $\mathrm{f}$. sp. raphani by either of the three bacterial strains (data not shown), indicating that the induced protection is unlikely to be caused by accumulation of Pseudomonas-produced antibiotics in the plant.

\section{Both WCS417r- and WCS358r-mediated ISR are independent of $\mathrm{SA}$.}

Using transgenic Arabidopsis NahG plants that did not accumulate SA (Delaney at al. 1994), Pieterse et al. (1996a) demonstrated that in contrast to pathogen-induced SAR, WCS417r-mediated ISR is independent of endogenous SA accumulation and PR gene activation. To investigate whether WCS358r-mediated ISR is independent of SA as well, bioassays were performed with NahG plants and wild-type Col plants. In accordance with previous results, treatment of the roots with WCS417r resulted in a significant reduction in symptoms caused by $P$. syringae pv. tomato infection in both Col and NahG plants (Fig. 3). WCS358r similarly induced protection in both wild-type and NahG plants, whereas plants
Pst
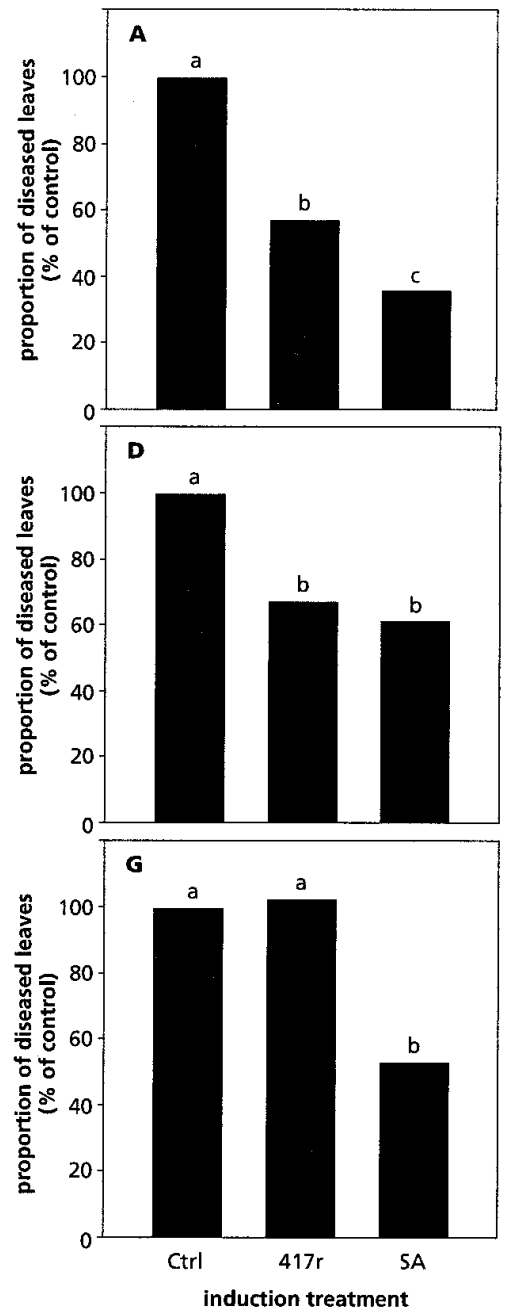
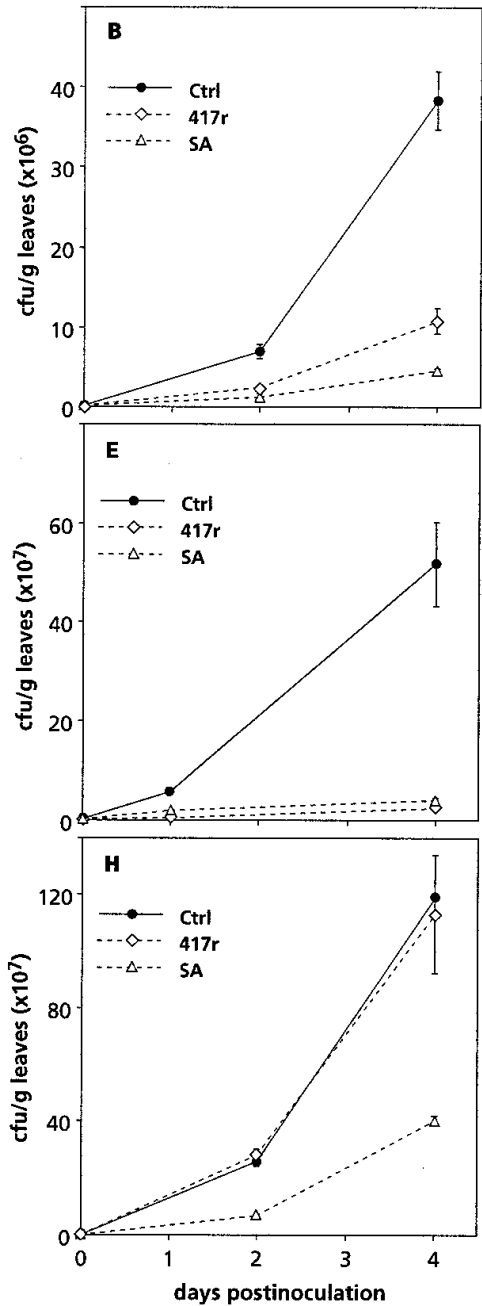

For
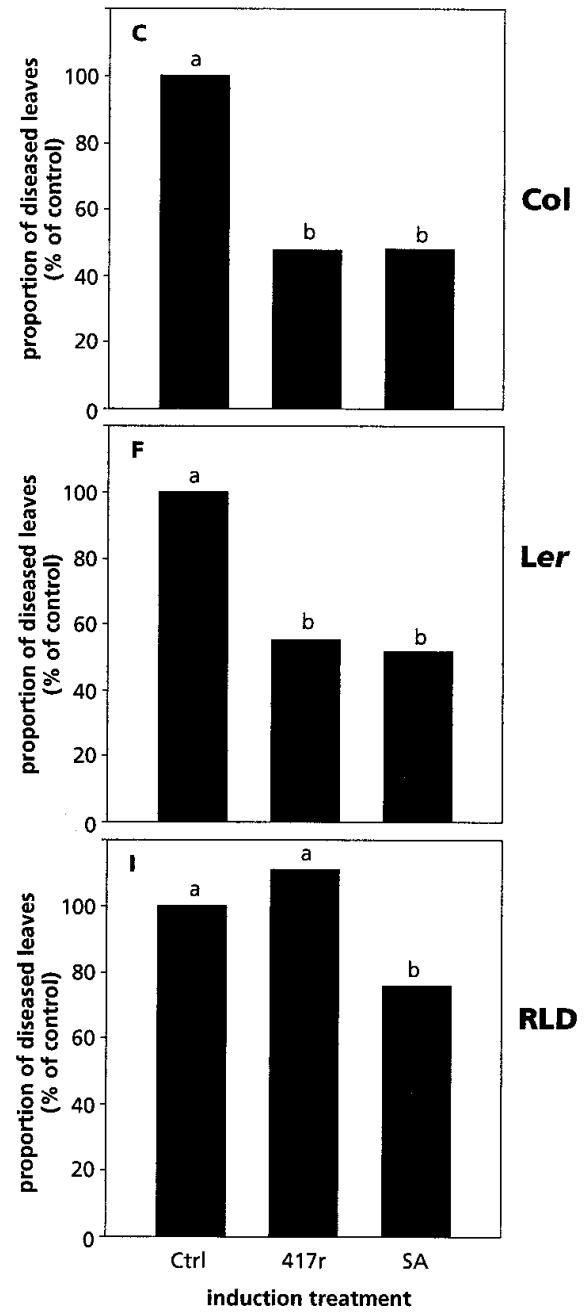

Fig. 1. Quantification of induced resistance against Pseudomonas syringae pv. tomato (Pst) or Fusarium oxysporum f. sp. raphani (For) infection in Col (A-C), Ler (D-F), and RLD (G-I) plants treated with $10 \mathrm{mM} \mathrm{MgSO}_{4}$ (Ctrl), P. fluorescens WCS417r (417r), or $1 \mathrm{mM}$ salicylic acid (SA). The proportion of leaves with symptoms relative to control plants (100\%) was determined 4 days after challenge inoculation with P. syringae pv. tomato (A, $\mathbf{D}$, and $\mathbf{G})$ or 3 to 4 weeks after challenge inoculation with $F$. oxysporum f. sp. raphani $(\mathbf{C}, \mathbf{F}$, and $\mathbf{I})$. The absolute proportions of diseased leaves of the controls shown in A, C, D, F, G, and I were 58.9, 53.4, 80.9, 61.2, 54.4, and 35.8\%, respectively. Different letters indicate statistically significant differences between treatments by Fisher's least significant difference test $(\alpha=0.05$, and $n=30)$. Growth of $P$. syringae pv. tomato in challenged leaves $(\mathbf{B}, \mathbf{E}$, and $\mathbf{H})$ was assessed at indicated days after inoculation. Data points are means (CFU/g) with standard errors from two sets of 20 leaves randomly selected from plants of the bioassays shown in $\mathbf{A}, \mathbf{D}$, and $\mathbf{G}$, respectively. The values presented are from representative experiments that were repeated at least twice with similar results. 
treated with WCS374r did not show increased resistance. The level of protection induced by WCS417 $r$ and WCS358 $r$ is somewhat lower in NahG plants compared with that in wildtype plants, suggesting a modulating role for SA in the level of expression of ISR. Northern blot analyses demonstrated that none of the rhizosphere pseudomonads induced PR-1, PR-2, or PR-5 mRNAs (Fig. 4). In contrast, PR mRNA accumulated in noninoculated leaves of plants expressing SAR induced by a predisposal infection of primary leaves with pathogenic $P$. syringae pv. tomato. These results demonstrate that like WCS417r, WCS358r elicits an SAindependent signaling pathway leading to ISR without concomitant activation of PR genes.

\section{Involvement of bacterial LPS in the elicitation of ISR in Arabidopsis.}

In radish, purified LPS and LPS-containing cell wall preparations of WCS417r are as effective as living WCS417r bacteria in inducing ISR (Leeman et al. 1995b). To investigate

Table 1. Colonization of the rhizosphere of Arabidopsis thaliana ecotypes Col, Ler, and RLD by WCS417 $\mathrm{r}^{\mathrm{a}}$

\begin{tabular}{|c|c|c|}
\hline \multirow[b]{2}{*}{ Ecotype } & \multicolumn{2}{|c|}{ CFU/g of root, fresh weight $\left(\times 10^{5}\right)^{b}$} \\
\hline & $\begin{array}{c}\text { Pseudomonas syringae } \\
\text { pv. tomato }\end{array}$ & $\begin{array}{l}\text { Fusarium oxysporum } \\
\text { f. sp. raphani }\end{array}$ \\
\hline $\mathrm{Col}$ & $2.2 \pm 0.2$ & $6.4 \pm 0.4$ \\
\hline Ler & $3.1 \pm 0.3$ & $3.9 \pm 0.2$ \\
\hline RLD & $6.0 \pm 1.0$ & $8.3 \pm 0.7$ \\
\hline
\end{tabular}

${ }^{a}$ Values presented are the average population densities \pm SE of multiple bioassays.

${ }^{\mathrm{b}}$ Roots were harvested at the end of the bioassays. On nontreated roots or root parts, no rifampicin-resistant bacteria were detected (detection limit $=10^{3} \mathrm{CFU} / \mathrm{g}$ ).

${ }^{c}$ Number of WCS417r bacteria on the roots of plants from the $P$. syringae pv. tomato bioassays.

${ }^{d}$ Number of WCS417r bacteria on the treated root parts of plants from the $F$. oxysporum f. sp. raphani bioassays. whether the LPS of WCS417r also elicits ISR in Arabidopsis, cell wall preparations of WCS417r and its mutant WCS417rOA ${ }^{-}$(Leeman et al. 1995b), which lacks the Oantigenic side chain of the LPS, were tested in P. syringae pv. tomato bioassays. Cell walls of the noninducing strain WCS374r were used as a control. Figure 5 shows that treatment of the roots with cell walls of WCS417r reduced

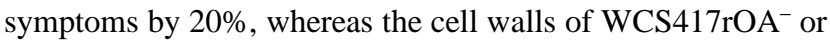
WCS374r were ineffective. The reduction was significantly less than the level of protection obtained with living bacteria, suggesting that the $\mathrm{O}$-antigenic side chain of the LPS of

Table 2. Colonization of Arabidopsis by WCS417r, WCS374r, and WCS358 ${ }^{\text {a }}$

\begin{tabular}{lccc}
\hline & \multicolumn{3}{c}{ CFU/g, fresh weight $\left(\times \mathbf{1 0}^{\mathbf{5}}\right)$} \\
\cline { 2 - 4 } Treatment $^{\mathbf{b}}$ & $\begin{array}{c}\text { Pseudomonas } \\
\text { syringae } \\
\text { pv. } \text { tomato }^{\mathbf{c}}\end{array}$ & $\begin{array}{c}\text { Fusarium } \\
\text { oxysporum } \\
\text { f. sp. } \text { raphani }^{\mathbf{d}}\end{array}$ & $\begin{array}{c}\text { Challenged } \\
\text { plant } \\
\text { parts }^{\mathbf{e}}\end{array}$ \\
\hline Control & b.d. & b.d. & b.d. \\
WCS417r & $3.1 \pm 0.2$ & $5.8 \pm 0.4$ & b.d. \\
WCS374r & $0.3 \pm 0.0$ & $0.7 \pm 0.1$ & b.d. \\
WCS358r & $3.0 \pm 0.3$ & $6.7 \pm 0.6$ & b.d. \\
\hline
\end{tabular}

${ }^{a}$ Values presented are the average population densities \pm SE of multiple bioassays. b.d. $=$ below detection (detection limit $=10^{3} \mathrm{CFU} / \mathrm{g}$ ).

${ }^{\mathrm{b}}$ In the $P$. syringae pv. tomato bioassays, a solution of $10 \mathrm{mM} \mathrm{MgSO}_{4}$ (control) or a suspension of Pseudomonas spp. strains in $10 \mathrm{mM}$ $\mathrm{MgSO}_{4}$ was mixed through the soil $\left(5 \times 10^{7} \mathrm{CFU} / \mathrm{g}\right)$ prior to planting of Ler. In the $F$. oxysporum f. sp. raphani bioassays, talcum powder mixed with a solution of $10 \mathrm{mM} \mathrm{MgSO}$ (control) or a suspension of Pseudomonas spp. strains in $10 \mathrm{mM} \mathrm{MgSO}_{4}\left(5 \times 10^{8} \mathrm{CFU} / \mathrm{g}\right)$ was applied to the lower part of the roots of 2-week-old Col seedlings.

${ }^{c}$ Number of rhizobacteria at the end of the bioassays on the roots of plants challenged with $P$. syringae pv. tomato.

d Number of rhizobacteria at the end of the bioassays on the treated root parts of plants from the F. oxysporum f. sp. raphani bioassays.

${ }^{\mathrm{e}}$ In the $P$. syringae pv. tomato bioassays, leaves were harvested just prior to challenge inoculation. In the $F$. oxysporum f. sp. raphani bioassays, inoculated upper root parts were harvested at the end of the bioassays.
Pst

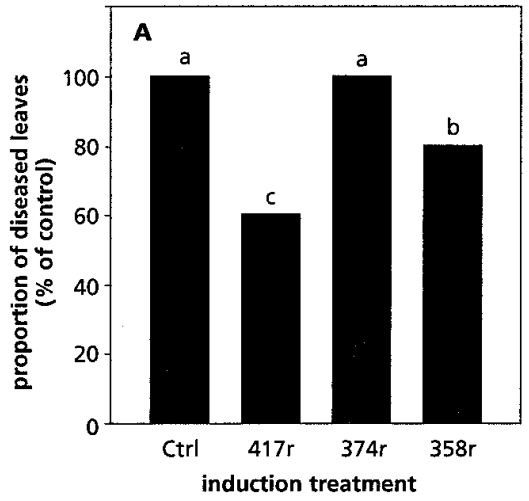

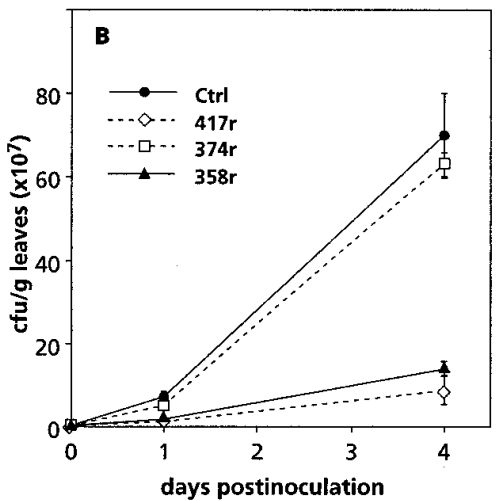

For

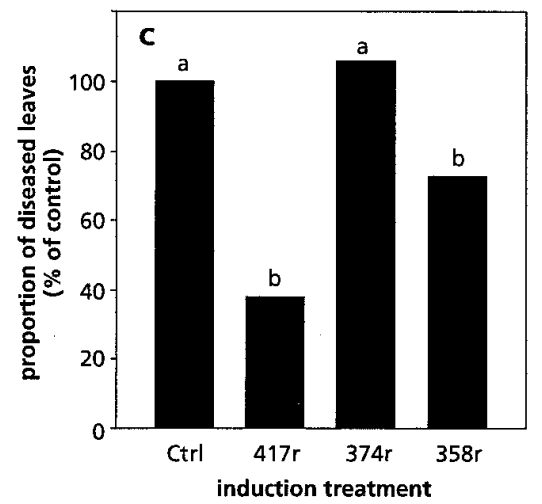

Fig. 2. Quantification of induced systemic resistance against Pseudomonas syringae pv. tomato (Pst) or Fusarium oxysporum f. sp. raphani (For) infection in Arabidopsis plants treated with $10 \mathrm{mM} \mathrm{MgSO}_{4}$ (Ctrl), P. fluorescens WCS417r (417r), P. fluorescens WCS374r (374r), or P. putida WCS358r (358r). The proportion of leaves with symptoms relative to control plants (100\%) was determined 4 days after challenge inoculation of Ler plants with $P$. syringae pv. tomato (A) or 3 to 4 weeks after challenge inoculation of Col plants with $F$. oxysporum f. sp. raphani (C). The absolute proportions of diseased leaves of the controls shown in $\mathbf{A}$ and $\mathbf{C}$ were 75.9 and 39.0\%, respectively. Different letters indicate statistically significant differences between treatments by Fisher's least significant difference test $(\alpha=0.05$, and $n=30)$. Growth of $P$. syringae pv. tomato in challenged leaves (B) was assessed at indicated days after inoculation. Data points are means (CFU/g) with standard errors from two sets of 20 leaves randomly selected from plants of the bioassay shown in $\mathbf{A}$. The values presented are from representative experiments that were repeated at least twice with similar results. 
WCS417r contributes to elicitation of ISR but is probably not sufficient for full induction.

Comparison of the resistance-inducing ability of living cells of WCS417r and its $\mathrm{OA}^{-}$mutant in Col and Ler plants revealed that in most experiments, wild-type and mutant bacteria induced similar levels of protection against both $P$. syringae pv. tomato and $F$. oxysporum $\mathrm{f}$. sp. raphani infection (Fig. 6A, B, and D). However, in some bioassays, the mutant was significantly less effective (Fig. 6C). WCS417r and WCS417 $\mathrm{rOA}^{-}$colonized the rhizosphere of Arabidopsis to similar levels (average of 3.6 and $3.4 \times 10^{5} \mathrm{CFU} / \mathrm{g}$ of root, fresh weight, respectively). These results demonstrate that in Arabidopsis, elicitation of ISR by WCS417r is not dependent upon the O-antigenic side chain of the LPS, although cell wall components can induce resistance and may contribute to the level of protection attained.

\section{DISCUSSION}

Induction of systemic resistance is one of the mechanisms by which selected strains of nonpathogenic Pseudomonas spp. can reduce diseases. $P$. fluorescens WCS417r has been demonstrated to induce resistance in several plant species (Duijff et al. 1996; Leeman et al. 1995a; Van Peer et al. 1991). With the aim of studying the molecular and mechanistic basis underlying this type of systemic resistance, we recently developed Arabidopsis as a model host using WCS417r as the inducing agent and $P$. syringae pv. tomato and $F$. oxysporum $\mathrm{f}$. sp. raphani as challenging pathogens (Pieterse et al. 1996a). ISR against $P$. syringae pv. tomato is manifested by both a reduction in the number of leaves showing symptoms and a decrease in the multiplication of the pathogen in the leaves. ISR against $F$. oxysporum f. sp. raphani was measured as a reduction in the percentage of leaves showing symptoms only.

Using three A. thaliana ecotypes and three rhizobacterial strains, we now demonstrate that specific interactions between the bacterial strains and the plant ecotypes determine

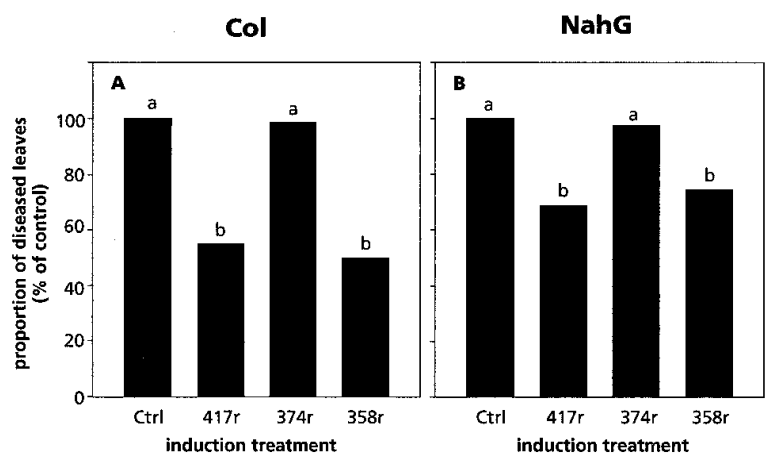

Fig. 3. Quantification of induced systemic resistance against Pseudomonas syringae pv. tomato infection in Arabidopsis Col (A) or NahG (B) plants treated with $10 \mathrm{mM} \mathrm{MgSO}$ (Ctrl), P. fluorescens WCS $417 \mathrm{r}$ (417r), P. fluorescens WCS374r (374r), or P. putida WCS358r (358r). Proportion of leaves with symptoms relative to control plants $(100 \%)$ was determined 4 days after challenge inoculation with the pathogen. The absolute proportions of diseased leaves of the controls shown in $\mathbf{A}$ and $\mathbf{B}$ were 58.5 and $80.1 \%$, respectively. Different letters indicate statistically significant differences between treatments by Fisher's least significant difference test $(\alpha=0.05$, and $n=30)$. The values presented are from representative experiments that were repeated at least twice with similar results. induction of systemic resistance. On the one hand, ecotypes of A. thaliana were differentially responsive to WCS417r treatment. In contrast to ecotypes Col and Ler, ecotype RLD did not develop ISR upon treatment of the roots with WCS417r (Fig. 1). Nevertheless, all three ecotypes readily expressed SAR upon SA treatment. Colonization of the rhizosphere by WCS417r was similar in the three ecotypes (Table 1), suggesting that ecotype RLD either does not recognize elicitors of WCS417r or is impaired in the ISR signaling pathway. On the other hand, bacterial strains WCS417r, WCS374r, and WCS358r were differentially active in the induction of ISR. WCS417r and WCS358r triggered an ISR response in Arabidopsis, whereas WCS374r did not (Fig. 2). In contrast, in radish, Leeman et al. (1995a) demonstrated induction by WCS417r and WCS374r but not by WCS358r. Apparently, all three strains have the potential to induce ISR but do so only in selected plant species.

Compared with the ISR-inducing strains WCS417r and WCS358r, the noninducing strain WCS374r was present at a 10-fold lower level in the rhizosphere of Arabidopsis by the end of the bioassays (Table 2). Therefore, it cannot be ruled out that the inability of WCS374 $r$ to trigger ISR in Arabidopsis is caused by insufficient root colonization. However, in the $F$. oxysporum f. sp. raphani bioassay, in which plants were challenged as soon as 3 days after application of the rhizobacterial strains, only the initial density of bacteria applied to the roots appeared critical for the induction of ISR, and bacterial numbers often dropped to noninducing levels by the end of the bioassays (Leeman et al. 1995a; Raaijmakers et al. 1995). Since treatments constituted equal amounts of the different bacteria at a concentration 500fold higher than the threshold for ISR in radish (Raaijmakers et al. 1995), the inability of WCS374r to induce ISR in this bioassay is more likely caused by a lack of response by the plant. This explanation is supported by our observation that cell wall preparations of WCS374r were ineffective in inducing ISR in Arabidopsis, in contrast to those of WCS417r,

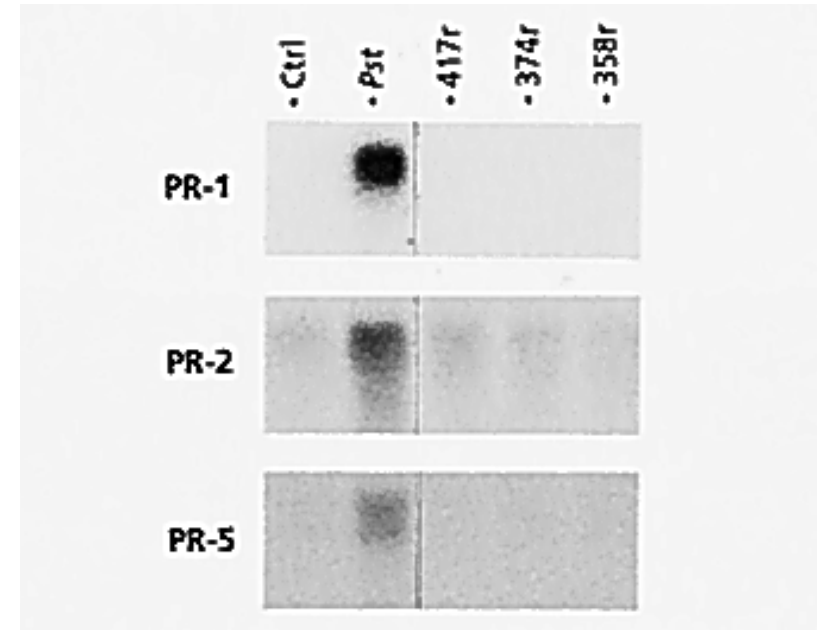

Fig. 4. Northern blot analyses of pathogenesis-related gene expression in leaves of 5-week-old Arabidopsis plants cultured in soil containing 10 $\mathrm{mM} \mathrm{MgSO}_{4}$ (Ctrl), Pseudomonas fluorescens WCS417r (417r), P. fluorescens WCS374r (374r), or P. putida WCS358r (358r), using PR-1, PR-2, and PR-5 gene-specific probes. Inoculation with $P$. syringae pv. tomato (Pst) was performed by pressure infiltrating three lower leaves 2 days before harvest of the noninoculated leaves. 
whereas cell wall preparations from both strains were active in eliciting ISR in radish (Leeman et al 1995b).

The ecotype-specific induction of resistance in Arabidopsis by WCS417r further indicates that protection against $P$. syringae pv. tomato and $F$. oxysporum $\mathrm{f}$. sp. raphani is dependent upon specific interactions between the bacteria and the plant. Direct suppression of the pathogen by bacterial antagonism can be ruled out, since the inducing pseudomonads and the challenging pathogens remained spatially separated (Table 2). Moreover, none of the bacterial strains significantly inhibited the pathogens in vitro, making it highly unlikely that accumulation of antibiotics produced by the rhizobacterial pseudomonads contributed to the increased protection.

A major bacterial trait implicated in the elicitation of resistance responses in plants by pathogens is the outer membrane LPS (Sequeira 1983). LPS-containing cell walls of WCS417r, which were able to elicit a full resistance response in radish and carnation (Leeman et al. 1995b; Van Peer and Schippers 1992), also induced protection in Arabidopsis (Fig. 5). However, the level of protection was significantly lower than that elicited by living bacteria. Moreover, the $\mathrm{OA}^{-}$mutant of WCS417r, which no longer induced ISR in radish (Leeman et al. 1995b), did reduce the disease symptoms in Arabidopsis in most experiments to the same extent as the wild-type (Fig. 6). This indicates that the LPS of WCS417r plays only a minor role in the elicitation of ISR in Arabidopsis and that other bacterial component(s) constitute the primary determinant.

SA produced by rhizosphere pseudomonads has been implicated in the activation of systemic resistance in radish (Leeman et al. 1996). However, bacterially produced SA is unlikely to be a determinant for eliciting ISR in Arabidopsis. First, both WCS417r and WCS358r induced ISR in Arabidopsis, but only WCS417r has the capacity to produce SA (Leeman et al. 1996). Moreover, WCS374r can produce the largest amount of SA but does not induce resistance in Arabidopsis. Second, inducing strains were equally effective

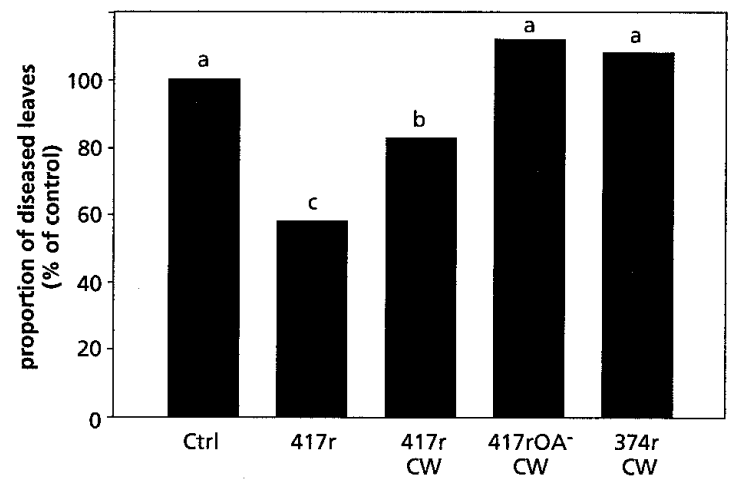

Fig. 5. Quantification of induced systemic resistance against Pseudomonas syringae pv. tomato infection in Arabidopsis plants treated with $10 \mathrm{mM} \mathrm{MgSO}_{4}$ (Ctrl), P. fluorescens WCS417r (417r), or cell wall preparations of WCS417r (417r CW), WCS417rOA ${ }^{-}\left(417 \mathrm{rOA}^{-} \mathrm{CW}\right)$, or $P$. fluorescens WCS374r $(374 \mathrm{r} \mathrm{CW})$. The proportion of leaves with symptoms relative to control plants $(100 \%)$ was determined 4 days after challenge inoculation of Ler plants with the pathogen. The absolute proportion of diseased leaves of the control was $65.5 \%$. Different letters indicate statistically significant differences between treatments by Fisher's least significant difference test $(\alpha=0.05$, and $n=30)$. The values presented are from a representative experiment that was repeated twice with similar results. in wild-type and NahG plants that readily inactivate SA. In addition, the $\mathrm{OA}^{-}$mutants of these strains had the same resistance-inducing capacity in NahG plants as the wild-type strains (data not shown), indicating that SA does not contribute to the ISR response elicited by the non-LPS determinant. Third, WCS417r did not trigger ISR in ecotype $\mathrm{RLD}$, although this ecotype is responsive to induction by SA (Fig. 1).

Another metabolite implicated in ISR induction is the ironregulated pyoverdine siderophore (Maurhofer et al. 1994). Leeman et al. (1996) demonstrated that the siderophore of WCS374r can act as an elicitor of ISR in radish, even though its effect is overridden by that of the LPS during the induction by living bacteria. We are currently investigating the involvement of siderophores in the elicitation of ISR in Arabidopsis.

As previously demonstrated for strain WCS417r (Pieterse et al. 1996a), WCS358r induces a plant-mediated resistance response in both wild-type and NahG plants without concomitant activation of genes encoding PR proteins (Figs. 3 and 4). These results indicate that both biocontrol strains induce a signaling pathway different from the one that controls classic SAR. Press et al. (1996) found that biocontrol strain Serratia marcescens $90-166$ is able to induce protection in both wild-type and $\mathrm{NahG}$ tobacco plants against $P$. syringae pv. tabaci as well. Hence, it seems that the ability to trigger an SA-independent pathway controlling systemic resistance is a common trait of ISR-inducing biocontrol bacteria.

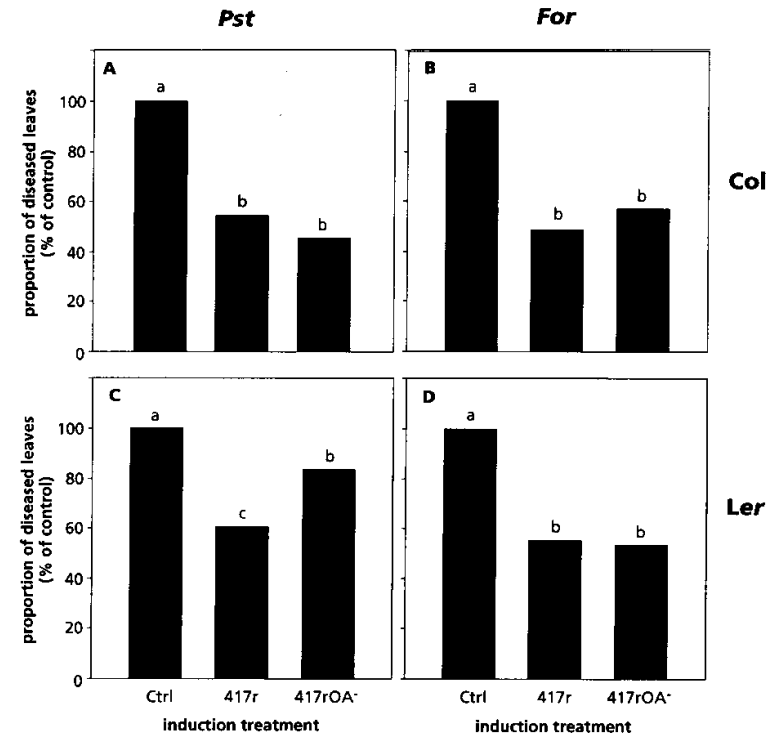

Fig. 6. Quantification of induced systemic resistance against Pseudomonas syringae pv. tomato (Pst) or Fusarium oxysporum f. sp. raphani (For) infection in $\mathrm{Col}(\mathbf{A}$ and $\mathbf{B})$ and $\operatorname{Ler}(\mathbf{C}$ and $\mathbf{D})$ plants treated with $10 \mathrm{mM} \mathrm{MgSO}_{4}$ (Ctrl), P. fluorescens WCS417r (417r), or its LPS Oantigen mutant WCS417 $\mathrm{rOA}^{-}\left(417 \mathrm{rOA}^{-}\right)$. The proportion of leaves with symptoms relative to control plants $(100 \%)$ was determined 4 days after challenge inoculation with $P$. syringae pv. tomato (A and C) or 3 to 4 weeks after challenge inoculation with $F$. oxysporum $\mathrm{f}$. sp. raphani (B and $\mathbf{C})$. The absolute proportions of diseased leaves of the controls shown in A-D were 58.9, 57.6, 73.3, and 61.2\%, respectively. Different letters indicate statistically significant differences between treatments by Fisher's least significant difference test $(\alpha=0.05$, and $n=30)$. The values presented are from representative experiments that were repeated at least twice with similar results. 


\section{MATERIALS AND METHODS}

\section{Microbial cultures.}

Pseudomonas fluorescens strain WCS417 was initially isolated from the rhizosphere of wheat grown in a field suppressive to take-all disease caused by Gaeumannomyces graminis pv. tritici (Lamers et al. 1988) and P. fluorescens strain WCS374 and $P$. putida strain WCS358 were collected from the rhizosphere of potato (strains WCS374 and WCS358) (Geels and Schippers 1983). Rifampicin-resistant mutants of these strains (WCS417r, WCS374r, and WCS358r) were used throughout this study (Geels and Schippers 1983; Glandorf et al. 1992; Leeman et al. 1991). WCS417rOA- is a spontaneous phage-resistant mutant of WCS417r lacking the $\mathrm{O}$-antigenic side chain of the outer membrane LPS (Leeman et al. 1995b). The bacteria were cultured for $24 \mathrm{~h}$ on King's medium B (KB) agar plates (King et al. 1954) at $28^{\circ} \mathrm{C}$. Subsequently, the cells were collected and resuspended in 10 $\mathrm{mM} \mathrm{MgSO}_{4}$.

The virulent bacterial pathogen $P$. syringae pv. tomato DC3000 (Whalen et al. 1991) was cultured in liquid KB at $28^{\circ} \mathrm{C}$. After overnight incubation, the cells were collected by centrifugation and resuspended in $10 \mathrm{mM} \mathrm{MgSO}_{4}$.

The fungal pathogen Fusarium oxysporum f. sp. raphani WCS600 was initially isolated from tubers of a naturally infected radish plant (Leeman et al. 1995a), and a culture was maintained on potato-dextrose agar. The inoculum was prepared by incubating mycelial patches in aerated $2 \%$ malt extract at $22^{\circ} \mathrm{C}$ for 7 days. Subsequently, cultures were filtered and conidia were collected by centrifugation. Conidia were mixed with sterile peat (Agrifutur s.r.l., Alfianello, Italy) to a density of $10^{7}$ conidia per gram and allowed to germinate and grow at $24^{\circ} \mathrm{C}$ for 2 days. The final density of colony-forming units in the peat was determined by dilution plating on potato-dextrose agar.

\section{Preparation of bacterial cell walls.}

Cell walls of WCS417r, WCS417rOA ${ }^{-}$, and WCS374r were isolated from cultures grown overnight in liquid $\mathrm{KB}$ at $28^{\circ} \mathrm{C}$, essentially as described by Leeman et al. (1995b). The bacteria were collected by centrifugation and resuspended in $50 \mathrm{mM}$ Tris- $\mathrm{HCl}$ plus $2 \mathrm{mM}$ EDTA ( $\mathrm{pH}$ 8.5). The cells were then sonicated eight times for $15 \mathrm{~s}$ on ice at resonance amplitude. Intact cells were removed from the sonicated suspension by centrifugation at $600 \times g$ for $20 \mathrm{~min}$. After centrifugation of the supernatant at $8,000 \times g$ for $60 \mathrm{~min}$, the pellet of LPS-containing cell walls was resuspended in $10 \mathrm{mM}$ phosphate-buffered saline $(\mathrm{pH} 7.2)$ plus $0.01 \%$ sodium azide and stored at $-80^{\circ} \mathrm{C}$ until further use. The absence of living bacteria was verified by plating on KB agar plates.

\section{$P$ syringae pv. tomato bioassay.}

Seeds of Arabidopsis thaliana ecotypes Columbia (Col), Landsberg erecta (Ler), RLD, and transgenic NahG plants harboring the bacterial $n a h G$ gene encoding salicylate hydroxylase (Delaney et al. 1994) were sown in sterile quartz sand. Once a day, the seedlings were supplied with modified halfstrength Hoagland nutrient solution $\left(2 \mathrm{mM} \mathrm{KNO}_{3}, 5 \mathrm{mM}\right.$ $\mathrm{Ca}\left[\mathrm{NO}_{3}\right]_{2}, 1 \mathrm{mM} \mathrm{KH} \mathrm{PO}_{4}, 1 \mathrm{mM} \mathrm{MgSO}$, and trace elements, pH 7) (Hoagland and Arnon 1938) containing $10 \mu \mathrm{M}$ Sequestreen (Fe-ethylenediamine-di[o-hydroxyphenylacetic acid]; CIBA-Geigy, Basel, Switzerland). Two-week-old seedlings were transferred to $60-\mathrm{ml}$ pots containing a sand and potting soil mixture that had been autoclaved twice for $1 \mathrm{~h}$ before it was mixed with either a suspension of pseudomonads to a final density of $5 \times 10^{7} \mathrm{CFU} / \mathrm{g}$ or an equal volume of a solution of $10 \mathrm{mM} \mathrm{MgSO} 4(50 \mathrm{ml} / \mathrm{kg})$. Treatment of the roots with bacterial cell walls was performed by applying $20 \mathrm{ml}$ of a cell wall preparation as a soil drench 7 and 4 days before challenge inoculation (cell walls from $2.5 \times 10^{6} \mathrm{CFU} / \mathrm{ml}$, resulting in an amount of cell walls equal to that present in soil containing $5 \times 10^{7} \mathrm{CFU} / \mathrm{ml}$ at the beginning of the bioassay). SA treatment was performed by applying $20 \mathrm{ml}$ of a solution of $1 \mathrm{mM} \mathrm{SA}(\mathrm{pH} 6)$ as a soil drench 7 and 4 days before challenge inoculation. Plants were cultivated in a growth chamber with a 9-h day $\left(200 \mu \mathrm{E} \mathrm{m}^{-2} \mathrm{~s}^{-1}\right.$ at $\left.24^{\circ} \mathrm{C}\right)$ and a 15 -h night $\left(20^{\circ} \mathrm{C}\right)$ cycle at $70 \%$ relative humidity. The plants were watered on alternate days and once a week supplied with nutrient solution.

Plants were challenge inoculated when 5 weeks old. One day before challenge, the plants were placed at $100 \%$ relative humidity. Inoculation was carried out by dipping the leaves in a suspension of $P$. syringae pv. tomato in $10 \mathrm{mM} \mathrm{MgSO}_{4}$ supplemented with $0.01 \%$ ( $\mathrm{vol} / \mathrm{vol}$ ) of the surfactant Silwet L77 (Van Meeuwen Chemicals BV, Weesp, the Netherlands). Inoculation densities were chosen such that 4 days after challenge, approximately $70 \%$ of the leaves of the control plants showed symptoms $\left(2.5 \times 10^{7} \mathrm{CFU} / \mathrm{ml}\right.$ for $\mathrm{Col}$ and NahG, $1 \times 10^{8} \mathrm{CFU} / \mathrm{ml}$ for Ler, and $1 \times 10^{7} \mathrm{CFU} / \mathrm{ml}$ for RLD). At that time, the proportion of leaves with disease symptoms per plant was determined for 30 plants per treatment. Data were statistically analyzed by one-way analysis of variance (ANOVA) for a single experiment and two-way ANOVA for combined experiments followed by Fisher's test for least significant differences at $\alpha=0.05$.

Multiplication of $P$. syringae pv. tomato was assessed in challenged leaves at different time points after inoculation. Two pools of $1 \mathrm{~g}$ of randomly selected leaves (15 to 20) per treatment were rinsed thoroughly in sterile water and homogenized in a sterile solution of $10 \mathrm{mM} \mathrm{MgSO}_{4}$. Dilutions were plated onto $\mathrm{KB}$ agar supplemented with rifampicin (50 $\mathrm{mg} / \mathrm{liter})$ and cycloheximide (100 mg/liter). After incubation at $28^{\circ} \mathrm{C}$ for 2 days, the number of colony-forming units per gram of infected leaf tissue was determined.

\section{F. oxysporum f. sp. raphani bioassay.}

Seeds of $A$. thaliana ecotypes Col, Ler, and RLD were sown singly in 1-ml pipette tips filled with sterile quartz sand to stimulate root elongation. The tips were drenched in water daily and in modified half-strength Hoagland nutrient solution once a week. After 2 weeks, seedlings were rinsed out of the pipette tips and placed horizontally on a system of rock wool cubes (Rock-wool/Grodan B.V., Roermond, the Netherlands), consisting of two spatially separated compartments. This system allows an induction treatment and a challenge inoculation of the same root system at different sites (Leeman et al. 1995a; Pieterse et al. 1996a). The lower part of the root system was covered with $1 \mathrm{ml}$ of a $1: 1(\mathrm{wt} / \mathrm{vol})$ mixture of talcum powder and either Pseudomonas bacteria in $10 \mathrm{mM}$ $\mathrm{MgSO}_{4}$ (final density $5 \times 10^{8} \mathrm{CFU} / \mathrm{g}$ ), a solution of $1 \mathrm{mM} \mathrm{SA}$ (pH 6), or a solution of $10 \mathrm{mM} \mathrm{MgSO}_{4}$ as a control. Three days after the induction treatment, the plants were challenge inoculated by applying approximately $0.25 \mathrm{~g}$ of the $F$. 
oxysporum $\mathrm{f}$. $\mathrm{sp}$. raphani inoculum $\left(4 \times 10^{6} \mathrm{CFU} / \mathrm{g}\right.$ of peat) to the upper part of the roots. Subsequently, plants were cultivated as described above.

Thirty plants per treatment were analyzed for induced protection against $F$. oxysporum $\mathrm{f}$. sp. raphani by determining the percentage of fully expanded leaves per plant with symptoms of Fusarium wilt at 3 to 4 weeks after challenge inoculation. The data were statistically analyzed as described above.

\section{Rhizosphere colonization.}

Bacterial colonization of the root (parts) was determined by the time the bioassays were discontinued. The roots of six plants of each treatment were harvested, weighed, rinsed briefly in water, and shaken vigorously for $1 \mathrm{~min}$ in glass tubes containing $5 \mathrm{ml}$ of $10 \mathrm{mM} \mathrm{MgSO}_{4}$ and $0.5 \mathrm{~g}$ of glass beads $(0.17 \mathrm{~mm})$. Appropriate dilutions were plated on $\mathrm{KB}$ agar supplemented with cycloheximide (100 mg/liter), ampicillin (50 mg/liter), chloramphenicol (13 mg/ liter), and rifampicin (150 mg/liter), which is selective for rifampicinresistant Pseudomonas spp. (Geels and Schippers 1983). After overnight incubation at $28^{\circ} \mathrm{C}$, the number of colony-forming units per gram of root, fresh weight, was determined.

\section{RNA analysis.}

For RNA extraction, leaves were harvested from 5-weekold plants that were either nontreated, treated with Pseudomonas rhizobacteria, or inoculated with $P$. syringae pv. tomato. Inoculation with $P$. syringae pv. tomato was performed by pressure infiltrating three lower leaves with a suspension of 1 $\times 10^{7} \mathrm{CFU} / \mathrm{ml}$ of $10 \mathrm{mM} \mathrm{MgSO}_{4}$ by using a syringe without a needle, as described by Swanson et al. (1988). Leaves were frozen in liquid nitrogen and stored at $-80^{\circ} \mathrm{C}$. RNA was extracted by the guanidine hydrochloride RNA extraction method as described by Logemann et al. (1987). Total RNA $(15 \mu \mathrm{g})$ was electrophoretically separated on denaturing formaldehyde-agarose gels and blotted onto Hybond- $\mathrm{N}^{+}$membranes (Amersham, 's-Hertogenbosch, the Netherlands) by capillary transfer as described by Sambrook et al. (1989). Northern blots were hybridized and washed as described previously (Pieterse et al. 1994) and exposed to a Kodak XOmat AR film. The DNA probes were labeled with $\alpha-{ }^{32} \mathrm{P}-$ dCTP by random primer labeling (Feinberg and Vogelstein 1983) with a Ready-To-Go DNA Labeling Kit (Pharmacia Biotech, Roosendaal, the Netherlands). PR-1, PR-2, and PR-5 probes originated from Arabidopsis PR-1, PR-2, and PR-5 cDNA clones, respectively (Uknes et al. 1992).

\section{In vitro antagonism assay.}

To test antibiotic activity by WCS417r, WCS374r, and WCS358r, the bacterial strains were spotted at three positions on $\mathrm{KB}$ and rhizosphere medium (Buyer et al. 1989) agar plates supplemented with $200 \mu \mathrm{M} \mathrm{FeCl}$ (Duijff et al. 1993). After incubation at $28^{\circ} \mathrm{C}$ for 2 days, a suspension of $P$. syringae pv. tomato $\left(1 \times 10^{7} \mathrm{CFU} / \mathrm{ml}\right)$ or $F$. oxysporum $\mathrm{f}$. sp. raphani $\left(5 \times 10^{6}\right.$ conidia/ml $)$ in $10 \mathrm{mM} \mathrm{MgSO}_{4}$ was sprayed evenly onto the plates. After an additional incubation for 2 days at $28^{\circ} \mathrm{C}$ for $P$. syringae pv. tomato or at $24^{\circ} \mathrm{C}$ for $F$. oxysporum f. sp. raphani, plates were inspected for the occurrence of zones of inhibited growth of $P$. syringae pv. tomato or F. oxysporum f. sp. raphani around the colonies of the biocontrol bacteria.

\section{ACKNOWLEDGMENTS}

Col and Ler seeds were provided by Maarten Koornneef and RLD seeds by the Nottingham Arabidopsis Stock Centre. We thank Alan Slusarenko for the gift of P. syringae pv. tomato strain DC3000 and John Ryals for kindly providing the Arabidopsis NahG seeds and PR-1, PR-2, and PR-5 cDNA clones. We thank Peter Bakker for critically reading the manuscript. This work was supported by the Life Science Foundation (SLW), which is subsidized by the Netherlands Organization for Scientific Research (NWO).

\section{LITERATURE CITED}

Alström, S. 1991. Induction of disease resistance in common bean susceptible to halo blight bacterial pathogen after seed bacterization with rhizosphere pseudomonads. J. Gen. Appl. Microbiol. 37:495-501.

Bakker, P. A. H. M., Van Peer, R., and Schippers, B. 1991. Suppression of soil-borne plant pathogens by fluorescent pseudomonads: Mechanisms and prospects. Pages 217-230 in: Developments in Agricultural and Managed-Forest Ecology, vol. 23. A. B. R. Beemster, G. J. Bollen, M. Gerlagh, M. T. Ruissen, B. Schippers, and A. Tempel, eds. Elsevier, Amsterdam.

Buyer, J. S, Sikora, L. J., and Chaner, R. L. 1989. A new growth medium for the study of siderophore-mediated interactions. Biol. Fertil. Soils 8: 97-101.

Delaney, T. P., Uknes, S., Vernooij, B., Friedrich, L., Weymann, K., Negrotto, D., Gaffney, T., Gur-Rella, M., Kessmann, H., Ward, E., and Ryals, J. 1994. A central role of salicylic acid in plant disease resistance. Science 266:1247-1250.

Duijff, B. J., Meijer, J. W., Bakker, P. A. H. M., and Schippers, B. 1993. Siderophore-mediated competition for iron and induced resistance in the suppression of Fusarium wilt of carnation by fluorescent Pseudomonas spp. Neth. J. Plant Pathol. 99:277-289.

Duijff, B. J., Alabouvette, C., and Lemanceau, P. 1996. Involvement of induced systemic resistance in the control of Fusarium wilt of tomato by Fusarium oxysporum strain Fo47 and Pseudomonas fluorescens strain WCS417r. Int. Org. Biol. Integrated Control Noxious Anim. Plants/West Palaearctic Reg. Sec. Bull. 19:120-124.

Feinberg, A. P., and Vogelstein, G. 1983. A technique for radiolabeling DNA restriction endonuclease fragments to high specific activity. Anal. Biochem. 132:6-13.

Gaffney, T., Friedrich, L., Vernooij, B., Negrotto, D., Nye, G., Uknes, S., Ward, E., Kessmann, H., and Ryals, J. 1993. Requirement of salicylic acid for the induction of systemic acquired resistance. Science 261: 754-756.

Glandorf, D. C. M., Brand, I., Bakker, P. A. H. M., and Schippers, B. 1992. Stability of rifampicin resistance as a marker for root colonization studies of Pseudomonas putida in the field. Plant Soil 147:135142.

Geels, F. P., and Schippers, B. 1983. Selection of antagonistic fluorescent Pseudomonas spp. and their root colonization and persistence following treatment of seed potatoes. Phytopathol. Z. 108:193-206.

Hammerschmidt, R., and Kuć, J. 1995. Induced Resistance to Disease in Plants. Kluwer Academic Publishers, Dordrecht, the Netherlands.

Hoagland, D. R., and Arnon, D. I. 1938. The water culture method for growing plants without soil. Calif. Agric. Exp. Stn. Bull. 347:36-39.

Hoffland, E., Pieterse, C. M. J., Bik, L., and Van Pelt, J. A. 1995. Induced systemic resistance in radish is not associated with accumulation of pathogenesis-related proteins. Physiol. Mol. Plant Pathol. 46:309-320.

Hoffland, E., Hakulinen, J., and van Pelt, J. A. 1996. Comparison of systemic resistance induced by avirulent and nonpathogenic Pseudomonas species. Phytopathology 86:757-762.

King, E. O., Ward, M. K., and Raney, D. E. 1954. Two simple media for the demonstration of phycocyanin and fluorescin. J. Lab. Clin. Med. 44:301-307.

Kloepper, J. W., Tuzun, S., and Kuć, J. A. 1992. Proposed definitions related to induced disease resistance. Biocontrol Sci. Technol. 2:349351.

Lamers, J. G., Schippers, B., and Geels, F. P. 1988. Soil-borne disease of wheat in the Netherlands and results of seed bacterization with pseudomonads against Gaeumannomyces graminis var. tritici. Pages 
134-139 in: Cereal Breeding Related to Integrated Cereal Production. M. L. Jorna and L. A. Slootmaker, eds. Pudoc, Wageningen, the Netherlands.

Lawton, K. A., Friedrich, L., Hunt, M., Weymann, K., Delaney, T., Kessmann, H., Staub, T., and Ryals, J. 1996. Benzothiadiazole induces disease resistance in Arabidopsis by activation of the systemic acquired resistance signal transduction pathway. Plant $\mathrm{J}$. 10:71-82.

Leeman, M., Raaijmakers, J. M., Bakker, P. A. H. M., and Schippers, B. 1991. Immunofluorescense colony-staining for monitoring pseudomonads introduced into soil. Pages 374-380 in: Developments in Agricultural and Managed-Forest Ecology, vol. 23. A. B. R. Beemster, G. J. Bollen, M. Gerlagh, M. T. Ruissen, B. Schippers, and A. Tempel, eds. Elsevier, Amsterdam.

Leeman, M., Van Pelt, J. A., Den Ouden, F. M., Heinsbroek, M., Bakker, P. A. H. M., and Schippers, B. 1995a. Induction of systemic resistance by Pseudomonas fluorescens in radish cultivars differing in susceptibility to Fusarium wilt, using a novel bioassay. Eur. J. Plant Pathol. 101:655-664.

Leeman, M., Van Pelt, J. A., Den Ouden, F. M., Heinsbroek, M., Bakker, P. A. H. M., and Schippers, B. 1995b. Induction of systemic resistance against Fusarium wilt of radish by lipopolysaccharides of Pseudomonas fluorescens. Phytopathology 85:1021-1027.

Leeman, M., Den Ouden, F. M., Van Pelt, J. A., Dirkx, F. P. M., Steijl, H., Bakker, P. A. H. M., and Schippers, B. 1996. Iron availability affects induction of systemic resistance to Fusarium wilt of radish by Pseudomonas fluorescens. Phytopathology 86:149-155.

Linthorst, H. J. M. 1991. Pathogenesis-related proteins of plants. Crit. Rev. Plant Sci. 10:123-150.

Logemann, J., Schell, J., and Wilmitzer, L. 1987. Improved method for the isolation of RNA from plant tissues. Anal. Biochem. 163:16-20.

Malamy, J., and Klessig, D. F. 1992. Salicylic acid and plant disease resistance. Plant J. 2:643-654.

Malamy, J., Carr, J. P., Klessig, D. F., and Raskin I. 1990. Salicylic acid: A likely endogenous signal in the resistance response of tobacco to viral infection. Science 250:1002-1004.

Maurhofer, M., Hase, C., Meuwly, P., Métraux, J.-P., and Défago, G. 1994. Induction of systemic resistance of tobacco to tobacco necrosis virus by the root-colonizing Pseudomonas fluorescens strain CHA0: Influence of the gacA gene and of pyoverdine production. Phytopathology 84:139-146.

Métraux, J.-P., Signer, H., Ryals, J., Ward, E., Wyss-Benz, M., Gaudin, J., Raschdorf, K., Schmid, E., Blum, W., and Inverardi, B. 1990. Increase in salicylic acid at the onset of systemic acquired resistance in cucumber. Science 250:1004-1006.

Métraux, J.-P., Ahl-Goy, P., Staub, T., Speich, J., Steinemann, A., Ryals, J., and Ward, E. 1991. Induced resistance in cucumber in response to 2,6-dichloroisonicotinic acid and pathogens. Pages 432-439 in: Advances in Molecular Genetics of Plant-Microbe Interactions, vol. 1. H. Hennecke and D. P. S. Verma, eds. Kluwer Academic Pub., Dordrecht, the Netherlands.

Pieterse, C. M. J., Derksen, A.-M. C. E., Folders, J., and Govers, F. 1994. Expression of the Phytophthora infestans ipiB and ipiO genes in planta and in vitro. Mol. Gen. Genet. 244:269-277.

Pieterse, C. M. J., Van Wees, S. C. M., Hoffland, E., Van Pelt, J. A., and Van Loon, L. C. 1996a. Systemic resistance in Arabidopsis induced by biocontrol bacteria is independent of salicylic acid accumulation and pathogenesis-related gene expression. Plant Cell 8:1225-1237.
Pieterse, C. M. J., Van Wees, S. C. M., Van Pelt, J. A., Trijssenaar, A., Van 't Westende, Y. A. M., Bolink, E. M., and Van Loon, L. C. 1996b. Systemic resistance in Arabidopsis thaliana induced by biocontrol bacteria. Med. Fac. Landbouww. Univ. Gent 61/2a:209-220.

Press, C. M., Wilson, M., and Kloepper, J. W. 1996. Salicylate and plant growth-promoting rhizobacteria-mediated induced systemic disease resistance. Abstract A-17 in: Proc. Int. Congr. Mol. Plant-Microbe Interact., 8th. G. Stacey, B. Mullin, and P. M. Gresshoff, eds. The University of Tennessee, Knoxville.

Raaijmakers, J. M., Leeman, M., van Oorschot, M. M. P., van der Sluis, I., Schippers, B., and Bakker, P. A. H. M. 1995. Dose-response relationships in biological control of Fusarium wilt of radish by Pseudomonas spp. Phytopathology 85:1075-1081.

Ross, A. F. 1961. Systemic acquired resistance induced by localized virus infections in plants. Virology 14:340-358.

Sambrook, J., Fritsch, E. F., and Maniatis, T. A. 1989. Molecular Cloning: A Laboratory Manual. 2nd ed. Cold Spring Harbor Laboratory, Cold Spring Harbor, NY.

Schippers, B. 1992. Prospects for management of natural suppressiveness to control soilborne pathogens. Pages 21-34 in: Biological Control of Plant Diseases, Progress and Challenges for the Future. E. C. Tjamos, G. C. Papavizas, and R. J. Cook, eds. Plenum Press, New York.

Sequeira, L. 1983. Mechanisms of induced resistance in plants. Annu. Rev. Microbiol. 37:51-79.

Swanson, J., Kearney, B., Dahlbeck, D., and Staskawicz, B. 1988. Cloned avirulence gene of Xanthomonas campestris pv. vesicatoria complements spontaneous race change mutants. Mol. Plant-Microbe Interact. 1:5-9.

Thomashaw, L. S., and Weller, D. M. 1995. Current concepts in the use of introduced bacteria for biological control: Mechanisms and antifungal metabolites. Pages 187-235 in: Plant-Microbe Interactions, vol. 1. G. Stacey and N. Keen, eds. Chapman and Hall, New York.

Uknes, S., Mauch-Mani, B., Moyer, M., Potter, S., Williams, S. Dincher, S., Chandler, D., Slusarenko, A., Ward, E., and Ryals, J. 1992. Acquired resistance in Arabidopsis. Plant Cell 4:645-656.

Van Loon, L. C. 1985. Pathogenesis-related proteins. Plant Mol. Biol. 4:111-116.

Van Peer, R., and Schippers, B. 1992. Lipopolysaccharides of plant growth-promoting Pseudomonas spp. strain WCS417r induce resistance in carnation to Fusarium wilt. Neth. J. Plant Pathol. 98:129-139.

Van Peer, R., Niemann, G. J., and Schippers, B. 1991. Induced resistance and phytoalexin accumulation in biological control of Fusarium wilt of carnation by Pseudomonas sp. strain WCS417r. Phytopathology 81:728-734.

Ward, E. R., Uknes, S. J., Williams, S. C., Dincher, S. S., Wiederhold, D. L., Alexander, D. C., Ahl-Goy, P., Métraux, J.-P., and Ryals, J. A. 1991. Coordinate gene activity in response to agents that induce systemic acquired resistance. Plant Cell 3:1085-1094.

Wei, G., Kloepper, J. W., and Tuzun, S. 1991. Induction of systemic resistance of cucumber to Colletotrichum orbiculare by select strains of plant growth-promoting rhizobacteria. Phytopathology 81:1508-1512.

Whalen, M. C., Innes, R. W., Bent, A. F., and Staskawicz, B. J. 1991. Identification of Pseudomonas syringae pathogens of Arabidopsis and a bacterial locus determining avirulence on both Arabidopsis and soybean. Plant Cell 3:49-59.

White, R. F. 1979. Acetylsalicylic acid (aspirin) induces resistance to tobacco mosaic virus in tobacco. Virology 99:410-412. 